\title{
THE KING OF THE DARK CHAMBER
}

\section{PAMUDURTHI VINATHA}

Associate Professor in English, Srinivasa Ramanujan Institute of Technology, Anantapuramu, India

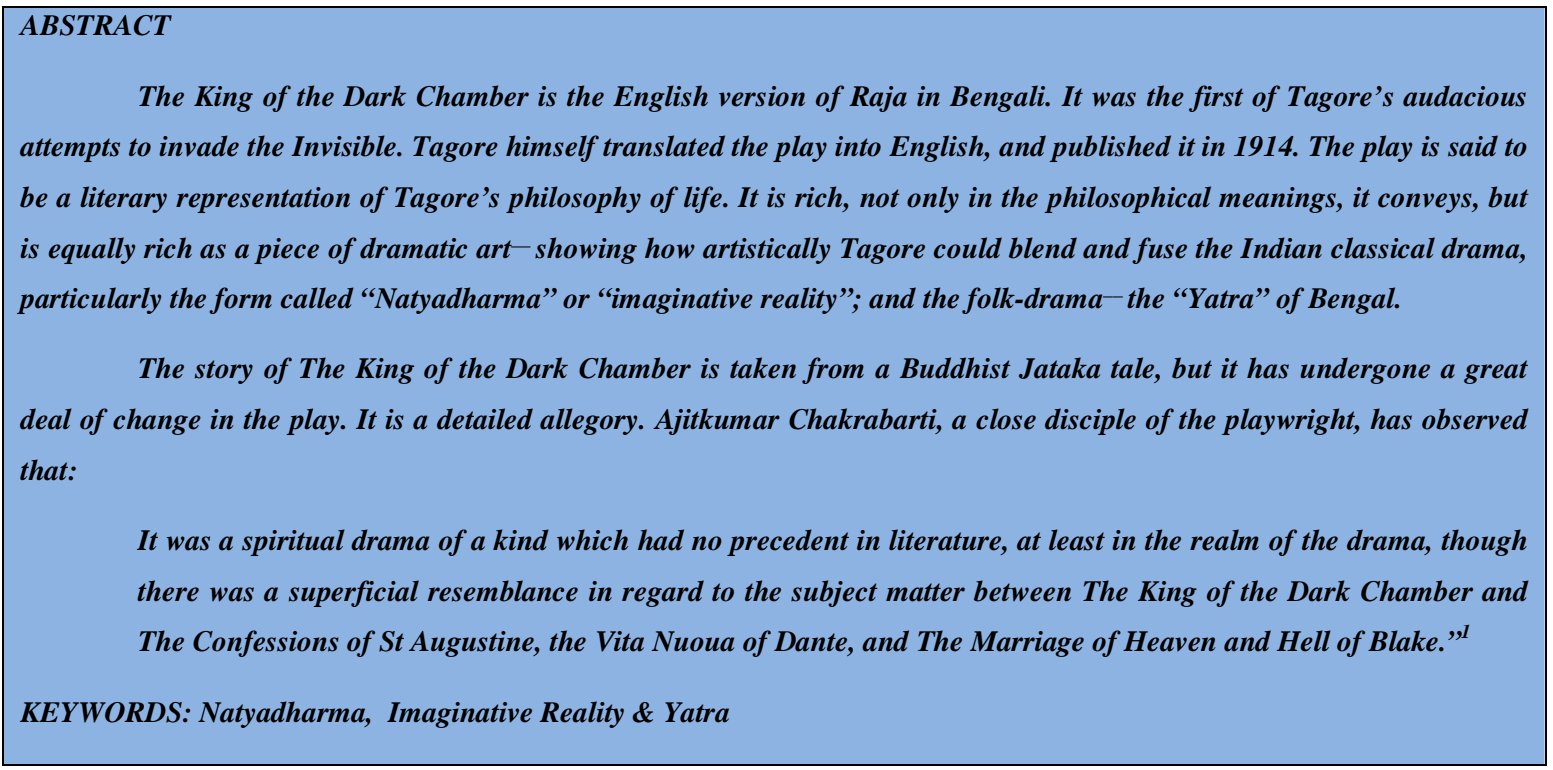

Received: May 02, 2017; Accepted: May 22, 2017; Published: Jun 05, 2017; Paper Id.: IJELJUN201710

\section{INTRODUCTION}

The King of the Dark Chamber is a play based on a story adapted from a Buddhist tale. But, it is entirely different from his earlier plays both in outline and detail. The general assessment of the play is that it is both obscure and difficult. It is a long play containing twenty scenes. The King used to meet his queen Sudarshana in a dark chamber. When she expresses her desire to see him, he advises her to find him out in the festival which is to be held at night. The queen sees a handsome man called Suvarna and mistakes him for the King. Many other kings have assembled for the festival led by the king of Kanchi, who has an infatuation for queen Sudarshana. There is anarchy under the very nose of the invisible King. They set the place on fire. The invisible King becomes visible for a moment, but Sudarshana is shocked by his ugliness. She runs to her father's house pursued by the king of Kanchi. The grandfather suddenly appears and defeats all the kings except the king of Kanchi, who is later defeated by the 'real King'. Sudarshana repents and surrenders to the King. King of Kanchi also yields to him.

The King of the Dark Chamber represents God and queen Sudarshana stands for the human soul. God sees all but is not seen by us. The human soul, always impatient to get united with the Supreme, also languishes to have a glimpse of Him. Nirmal Mukherji says:

The unseen King represents God whom man cannot see, but can realize in the dark chamber of his inner consciousness. Queen Sudarshana symbolizes the human soul which is ignorant of its own identity, as well as of the true nature of divinity. The knowledge of the true nature of God comes through self-realization. ${ }^{2}$ 
Darkness of the chamber signifies the seclusion of this world and physical beauty. Light, on the other hand, is the symbol of truth and spiritual beauty, which the Queen happens to achieve only at the end, when the King says, "I open the door of the dark room today- the game is finished here? Come, come with me now, and come outside into the light". (199) Like God Himself, the King remains a mystery to all from the beginning to the end of the play. Neither the Queen nor anyone else recognizes him. His subjects imagine, "The King is hideous to look at, so he has made up his mind never to show himself to his subjects." (150) The King himself is also conscious of the fact that his physical appearance is intolerable to the commoners. He himself says to the queen, "You will not be able to bear the sight of me-it will only give you pain, poignant and overpowering." (151) To mortal eyes he is unattractive and ugly. They know nothing beyond physical appearance. Hence, they cannot stand the sight of God represented by the King of the Dark Chamber. Queen Sudarshana, whose name means, 'one who looks beautiful" and 'one who sees well', says to Surangama, "I do not see anything distinctly in the dark. I do not know where the doors are." (150) Sudarshana representing the human soul earnestly longs to have a sight of the King who represents God:

Oh! Do show me for an instant how to see with your eyes. Is there nothing at all like darkness to you? I am afraid when I think of this. This darkness which is to me real and strong as death-is this simply nothing to you? Then how can there be any union at all between us, in a place like this? No, no-it is impossible: there is a barrier between us two: not here, no, not in this place. I want to find you and see you where I see trees and animals, birds and stones and the earth. (153-154)

In the beginning Sudarshana has nothing to do with spiritual beauty which at last she realizes later,

"You are not beautiful, my lord-you stand beyond all comparisons! Your love lives in me-you are mirrored in that love, and you see your face reflected in me: nothing of this mine, it is all yours, O Lord!" (199)

The queen thus confirms that God is within the human soul and the human soul lies within God. Thus the temporal and the celestial are united together.

The king of this play meets his queen only in a dark chamber. On her insistence he agrees to appear in the crowd on the day of the Spring Festival. None of his subjects had ever seen him; some even doubt his very existence. On the festival day, Suvarna, the impostor proclaims he the king. His physical charm deceives the queen into believing that he is the real king. Another king, the king of Kanchi, wants to possess the queen, sets the palace on fire. The frightened queen seeks the protection, but is utterly disillusioned when she discovers that Suvarna is a coward. At this crucial moment the real king appears and shocks the queen by his ugly looks. Accompanied by Surangama, the queen runs away to her father's house. She is heartily pursued by seven vassal kings, including Suvarna and the king of Kanchi. At this moment Thakurdada appears on the scene, and defeats all the kings except the rebel king of Kanchi. The valiant king of the Dark Chamber makes his sudden appearance, defeats the king of Kanchi, and disappears again. The queen decides to surrender to the King. In the last scene the queen finds the king and says:

Your sight repelled me because I had sought to find you in the pleasure garden, in my queen's chamber; there even your meanest servant looks more handsome than you. That fever of longing has left my eyes forever. You are not beautiful, my lord-- you stand beyond all comparison!' and the king replies most enigmatically:' I open the door of this dark room today-- the game is finished here? Come; come with me now; come outside-- into the light! (199) 
Sen Gupta finds the decisive influence of Vaishnava ideology on the allegorical framework of the play. The unseen King represents God whom man cannot see, but can realize in the dark chamber of his inner consciousness. Queen Sudarshana symbolizes the human soul which is ignorant of its own identity, as well as of the true nature of divinity. The knowledge of the true nature of God comes through self-realization.

The King of the Dark Chamber is tighter than the Bengali original and consequently more effective. "Its theme is somberly impressive", says Edward Thompson, "a magnificent attempt to dramatize the secret dealings of God with the human heart". ${ }^{3}$ There is speculation about the King all the time, and everyone in the play is involved in the tangle of thought, feeling and theorizing.

The drama opens on a street with a few wayfarers and a city guard. When a wayfarer asks the city guard, which way he should go to attend the big festivities, he replies that one street is as good as another. This is a significant statement, for it expresses the hidden idea that different paths may lead to the presence of God. But the path must be sincerely followed. He says: “Any street will lead you there. Go straight ahead, and you cannot miss the place.”(138)

Both the plot and the characters of the play are the symbolic representations of the struggle between illusion and truth. Two major lines of action found in the play are (i) the queen's search for and the intense desire to see the King, and (ii) the moves made by the king of Kanchi to spread chaos in the kingdom and to possess the queen. With great craftsmanship Tagore interweaves and synthesizes both lines of action. In structure, the play follows the five stages of development prescribed by the rules of classical dramaturgy. To appreciate how successfully Tagore builds the play on the lines of the "Natyadharma" form of Sanskrit drama, it would be of use to mention the classic five stages of development. According to the classical rules of drama, they are

- "Mukha": the opening.

- 'Pretimukha' the progression.

- 'Garbha': development.

- 'Vimarka': the pause.

- 'Nirvana': the conclusion.

In the first line of action, the dark chamber scene marks the opening. As the queen gives a garland to the false king, the progression begins: The third stage, of garbha begins with the scene in which the queen repents and the king reveals his terrible face. The pause is marked by the queen's realization of the mystery of the dark chamber. With the Scene VI in Act III (the road-scene) the conclusion begins. The final scene- the dark chamber again -presenting the queen surrendering herself to her king, marks the completion. Similar division can be observed in the second major line of action in the play. From the folk - play - 'Yatra' - tradition, Tagore takes another dramatic element, which he finally blends with the classical one. The chorus of citizens introduced in the play provides comments on the main action of the play, and imparts the touch of broad humor.

The fine balance maintained by Tagore in evoking the sentiment (RASA) also reveals his skill as a dramatist. The fire- scene is judiciously managed so as not to arouse extreme terror: the wonders of the dark chamber do not embarrass the audience. The lyrical tone of the dialogues and the delicacy of symbolism contribute to this end. 
The King of the Dark Chamber is based on the theme of Aham. In this play, there is a continuous strife between Aham and the lower self. The queen Sudarshana stands for the human being and her husband "The King" stands for the ideal of human life. The ideal can never be achieved as long as the lower self, the Aham in the man is not directed and guided by the higher self. The queen is directed by her Aham or the lower self and hence she does not get her husband during her life. The King is never seen by her. She says

Terrible, oh, it was terrible! I am afraid even to think of it again. Black, black-oh, thou art black like the everlasting night! I only looked on there for one dreadful instant. The blasé of the fire fell on your features-you looked like the awful night when a comet swings fearfully into our ken—oh then I closed my eyes-I could not look at you anymore. Black as the threatening storm-cloud, black as the shoreless sea with the spectral red tint of twilight on its tumultuous waves! (140)

The King reminds her gently: "Have I not told you before that one cannot bear my sight unless one is already prepared for me?"(140) the' whisky priest' in Graham Greene' The Power and the Glory tries to describe the strange nature of God's to the Lieutenant:

God is love. I don't say the heart doesn't feel a taste for it, but what a taste. The smallest glass of love mixed with a pint of ditch-water. We wouldn't recognize that love. It might even look like hate. It would be enough to scare us --God's love. It sets fire to a bush in the desert, didn't it, and smashed open graves and set the dead walking in the dark Oh, a man like me would run a mile to get away if he felt that love around. (141)

So, it is with Sudarshana, she flees to her father's place, unable to bear the King's love. With Surangama sustaining her always, Sudarshana learns the hard way of suffering and surrendering of her and unites with her King at last. Reason has received into itself the soul of faith and true devotion, Sudarshana has received in the Dark Chamber of her Heart the King of the Dark Chamber. There is no need any more for a blanket of darkness: they can go out together into the light!

What is this extraordinary play about? Quite obviously, the king symbolizes God. He is everywhere, he is everything, --hence he is nowhere, and nobody, in particular. Each in his littleness or half-knowledge makes out what he can of him. Some deny his very existence. Some try to assume his name and usurp his functions. And some implicitly, blindly, accept him and are content. While the queen has her doubts, the mere Maid of Honor is surely stationed in faith. She knows that the king will not abandon his subjects, much less than his queen:

If he leaves us like that, then we have no need of him. Then he does not exist for us: then dark chamber is totally empty and void--- not Vina ever breathed its music there---none called you or me in that chamber; then everything has been a delusion and an idle dream. (185)

Since the drama is about the soul's adventures in its attempts to know God, many of the subsidiary symbols fall into their appropriate places to render intelligible the zigzag progress of the soul towards the point of no return. The king himself is verily the Hound of Heaven pursuing the errant soul till he has seized and redeemed it. Since the two main actors in the drama are the king and his queen-God and the Jiva---the other characters should be seen as aids or impediments that help or hinder Sudarshana in her soul's quest for certainty. While Rohini is but a deceptive will-o'-the-wisp, Surangama is the psychic soul; the safety-valve behind Sudarashana's agitated and bewildered desire-soul. The grandfather who has lost his five children is the man of steady wisdom who has mastered his senses. Indeed, the 'stage' where the 
action of the play unfolds itself is the mind and the heart of man: the battles are fought in the theatre of the soul: and it is only when Sudarshana are willing to lose all—the last shred of her pride, even---that she gains all, and is in a position to march out Master from the Dark into the Light.

Sudarshana always meets the King in the dark chamber, who remains unseen to her. She is like a man who is ignorant and has an ego or Aham or like a blind man guided by another blind. As bars of the cage confine the birds, the greed for material things makes the life of a man confined within the material world. Those who are attached to these things never transcend the limit of matter like Sudarshana. The unseen King is God who likes a husband woos the human soul represented by Sudarshana. Sudarshana searches the King in the outer world as she is guided by her lower self, and never gets the King. At last, through severe miseries and struggles, she realizes her true self, surrenders her Aham and achieves the King.

The play reveals the mystic truth that, God lives in our heart. Sudarshana are like a deer who feels sweet fragrance coming to her with the wind and wanders in pursuit of it, and does not realize that he himself is the source of that fragrance. Kabir, the great mystic poet, says:

Mo ko Kahan dhundo bande

O servant, where dost thou seek Me?

Lo! I am beside thee.

I am neither in temple nor in mosque:

I am neither in Kaaba nor in Kailash:

Neither am I in rites and ceremonies, nor in

Yoga and renunciation.

If thou art a true seeker, thou shalt at once see me:

Thou shalt meet Me in a moment of time

Kabir says, 'O Sadhu! God is the breath of all breath.'

Queen Sudarshana is united to her King at the end of the play; the human soul at last realizes God within itself. The King flings open the door of the dark room: "I open the doors of this dark room today. The game is finished here? Come with me now come outside into the light!"(199)

The King is dark, his appearance repulsive because God is formless. Finite is always in search of infinite. This drama is about soul's adventure in its attempt to seek God. The two main characters in the play are 'God and Jiva'. God is achieved only by self- purification, by Adhyatmayoga and by freeing oneself from greed and Avidya. Avidya prevents our spiritual self from the works of sacrifice and stores everything in its own store house. In Kathopanishad, same thing has been said:

The men, who live in this world are in the midst of ignorance or thick darkness. They are ignorant but regard themselves as intelligent, they do not attain salvation. "This is the world," foolish thinks, "There is no other," thus falls again and again in the wheel of births and deaths. ${ }^{4}$ 
By deliverance of Avidya and pride, man gets real knowledge and light. Tagore wants to lead us from untruth to truth, from darkness to light and from mortality to immortality. Sudarshana is the symbol of human soul yearning to transcend earthly limitations and reach god. Tagore writes:

So, we must know that the meaning of our self is not to be found in its separateness from God and others, but in the ceaseless realization of Yoga, of union; not in the side of the canvas where it is blank, but on the side where the pictures is being painted. ${ }^{5}$

\section{And Again}

To be rescued from this fetter of words, we must rid ourselves of the avidya, our ignorance, and then our mind will find its freedom in the inner idea. ${ }^{6}$

In the middle of activity, we can achieve God because he lives in the innermost heart of every human being, not in the lonely dark corner. Sudarshana (The Soul) achieves the King (The God) not in the dark chamber but outside.

The play is obviously an attempt to put into dramatic form, the Vaishnava philosophy of the relationship between God and the Soul, and the play is perfectly intelligible to one who is acquainted with this philosophy. The King is established very early in the play as an allegorical figure, he is, of course, God, who never shows himself. The Grandfather clearly explains, “... Why, the whole country is filled and crammed with the King... "(169) This sentence itself suggests that the intellectual meaning is more important than the surface meaning, and that we are supposed to hold on to the intellectual meaning alone. Take, for instance, the following conversation.

Bhavadatta: It strikes me, Koundilya that these people haven't got a King at all. They have somehow managed to keep the rumour afloat.

Koundilya: You are right, I think...

Janardana: But look at the nice order and regularity prevailing all over the place-how do you explain it without a King?

Bhavadatta: Where would be the necessity of having a King if order and harmony existed already? But where is the King? Have you seen him?

Koundilya: Have you, or have you not, seen the King? Yes or no? (Exeunt). (118-119)

Then enters a band of Men, singing a song which is an answer to the question: 'Have you, or have you not seen the King?' They sing

My beloved is ever in my heart

That is why I see him everywhere....(221)

The King's relations with queen Sudarshana, for instance, do not often make sense on the surface level, and we are forced to take into consideration only the ideas that they stand for: the King symbolizes God; the queen symbolizes 'Jeeva' (the Soul). On the surface level— the queen who is married to the King has never seen him, and she meets him only in the dark chamber; it is her maid-of- honour, Surangama, who knows everything about the King. This makes sense only on the level of ideas: the soul is united to God even before it becomes conscious of it; the soul meets God only in the heart 
(the Dark Chamber); and it is intuition (Surangama) that knows God first and gives to the soul the intimations of God. Or else how can we conceive of a marriage in which the wife doesn't know about her husband and hasn't even seen him? Once we accept this, the allegory and drama go hand in hand for some time: The queen gets restless, yearns to 'see' her husband, is drawn towards the Pretender (some false ideas of God) to whom she sends flowers. From this point onwards, Tagore wants us to respond to the situation emotionally (as though it is a real- life situation) and consider the queen's desire for the Pretender as sin. The queen feels ashamed, prays to the God of fire, "burn me, burn to ashes my shame, my longing, my desire.”(106) when she meets the King in the dark room she begs him to punish her and later rushes out, saying: "If I stay with you I shall constantly be pursued and hounded by the thought that I am impure, that I am false and faithless." (114) the whole scene (scene VIII) is wonderful, psychologically valid on the surface level, and our responses get emotionally charged, since the situation of 'women-lover-husband' does evoke a strong emotional reaction. The surface-realistic level gets more attraction and the real meaning is left to take care of itself. This is seen more clearly in scene IX, in which the queen goes to her father, King of Kanya Kubja, who upbraids her:

When woman swerves from the right path, then she appears fraught with the direst calamity... she is coming to my home laden with peril and danger. She has faithlessly left her husband... she has left her palace as the Empress of her own accord-here she will have to work as a maid-servant if she wants to stay in my house...(122-123)

Here Tagore is carried away by the charms of a naturalistic situation, and the allegory gets clouded, vitiated, and the play gets hopelessly muddled.

A study of The King of the Dark Chamber shows that Tagore first starts with ideas, and then tries to embody them in an allegorical situation. While working out the situation in terms of drama, he lends himself to the naturalistic possibilities in the situation. He arouses emotions which are far beyond the thought- bound allegory. Tagore doesn't often succeed in harmonizing the emotional-human level and the allegorical-intellectual level, and the reason for this failure is that he, after carefully constructing a 'palace of art', attempts to put life into it artificially by straying into the emotionalrealistic mode. Sujit Mukherjee thinks it is, "inadequate dramatic presentation and the chaos of symbols concealing the simple allegory that are responsible for the failure of the play."7 The play fails, as we have seen, for an entirely different reason. It is the over-elaborate working out of the allegory, straying into the realistic-emotional area, which vitiates the drama; and then the emotional working out does not add any extra dimensions to the allegory; it succeeds, instead, in complicating what is simple, in making crooked what is clear and limpid.

The characters in The King of the Dark Chamber lack individuality. The play fails to make an impact. A play cannot succeed just because it has a central informing idea; it needs characters alive with their hopes, fears, contradictions, conflicts-characters pulsating with life. In this particular play the only character who has some consistency and credibility and whose actions dramatically motivated is the king of Kanchi. His one passion in life is to possess queen Sudarshana. All his plans, from setting the palace on fire to attacking the king of Kanyakubja are dramatically motivated by this masterpassion. He is valiant, dignified and strong, and the playwright seems to be in love with this character, though a bit reluctantly. Whereas he has dismissed the rest of the kings, he cannot do the same to the king of Kanchi, who is subsequently not only honoured but also saved to become a spiritual wayfarer. But the way he resolves his conflict and 'seeks the end of the earth to pay him his humble homage' is dramatically unconvincing and unsound. The change, if it is there, has come all too suddenly and is entirely untenable, because we are not prepared for it. Perhaps there is some uneasiness that the playwright feels at this point and reflects it through Kanchi, "I still cannot get rid of the feeling of a 
sacred dread of being laughed at by people when they see me meekly doing my homage to your king acknowledging my defeat." (183) The king of Kanchi is entirely human in his fear of being mocked at. The play ends on a didactic note, as it is usual in an allegory the queen and the King of Kanchi simultaneously discover that the meaning of life lies in seeking oneness with the divine, by meekly giving all that one has and realizing one's essential self. The unseen King who remains at the level of a principle does not attract us. Surangama, for whatever purpose she has been thrown in, is hardly interesting; rather, she is a constant irritant who infuriates by acting superior as an omniscient observer. The only convincing characters are citizens, nameless, erring, curious, but nonetheless, human.

It is difficult to agree with Sen Gupta who says, "The King of the Dark Chamber' is a remarkable achievement as a symbolic drama". Commenting further on the success of the symbolic mode of the plays, he says, "The excellence of the drama consists not so much in the facility with which two parallel sets of meaning may be brought out as in the manner in which the symbols of the human story project a mystical experience. Not only are the symbols magnificently conceived but one plane of meaning passes very easily into and is, indeed, completed in the other". ${ }^{8}$ The two planes of meaning, as a matter of fact, instead, of completing each other, create only confusion. If it were the intention of the dramatist to write an allegory play, which it apparently was, he does not go very far in that direction. Crude realistic details, such as the deadly missile fired by Grandfather which hurts the king of Kanchi, helps very little to project the symbolic meaning of the play. In the most crucial part of the play the surface meaning fails to further the symbolic design.

Another irritant in this play is the ever-present Thakurdada. He hardly has any dramatic relevance. If it was Tagore's intention to pattern Thakurdada after Shakespeare's Fool or Falstaff, then he has miserably failed. Thakurdada is a big nuisance. It is an error of judgment on Tagore's part that this character has to bear the burden of the dramatic unfolding and development. This all-knowing, ever-present Thakurdada resembles the proverbial Narada Muni of Hindu mythology.

As far as the other characters are concerned, Surangama has certainly very little dramatic justification to be where she is in the plot. The King obviously is an allegorical figure, a walking idea without individuality or adequate representational power nameless and bodiless. He stands for many things, among which the principles of order and harmony are the foremost.

Allegory in general and allegory in drama is a very difficult mode to handle. Since it implies the dominance of theme over action and image, the allegorical is very likely to doctor the action so that it conforms to theme and precept. One can agree with Elder Olson when he says, "The allegorical incident happens, not because it is necessary or probable in the light of other events, but because a certain doctrinal subject must have a certain doctrinal predicate; its order in the action is determined not by the action as action, but by the action as doctrine." ${ }^{9}$ Olson is right in its doctrinal rigidity. Further, characters in an allegory do not necessarily have to be mere walking ideas; they can have their individuality; for example, Christian in Bunyan's The Pilgrim's Progress is an individualized allegorical figure.

The King of the Dark Chamber is the first really symbolic drama by Tagore. Here the symbolism is clearer than in his other plays. The story is purely allegorical and simple. Nobody in the kingdom had ever seen the King. Even the queen did not see him and the King meets her always in a dark chamber. Still there was order and peace in the kingdom. The queen Sudarshana is somewhat egoistic and she is very anxious to see her husband in the daylight. The maid Suranguma, whom the King puts in charge of the Dark Chamber, knew the King well, though she also had never seen him. There were citizens like the grandfather who believed the King to be all powerful and there were citizens also like Virupaksha who did 
not believe even in the King's existence. But all were given a place in the kingdom.

However, queen Sudarshana insists to see the King, in spite of admonitions of the latter and of Suranguma. As a result on the day of a festival, she mistakes one pretender to be the King, and sends a garland. The impostor king encouraged by the conspirators-the kings of Koshala, Kanchi and Avanti-accepts the garland and sends her another one. But soon, unable to hide his own pretensions, the false king reveals himself. The queen, after the recognition, feels wounded with shame and pride and forsakes the King and goes to her father's kingdom. Meanwhile, the conspirators wage war against her father to seize her. But the King of the Dark Chamber conquers them all, in time, and the conspirators, and the queen, feel repentant and bow at his feet in humiliation.

The allegory in this drama is quite clear. The King stands for God or ultimate Reality, and the queen, for Maya, and his Dark Chamber represents death. Like the citizens in the play, we are all living in the world created by God. Yet we have never seen Him. Among us there are wise people, who have faith in God, like the grandfather in the play. Also there are tyrants, and atheists, in this world, like Virupaksha. Also there are orthodox hypocrites, like Bhavadatta and Kaundilya, who deceive themselves, because of their own pride in their so-called wisdom. There are rebels like the kings of Kanchi, Koshala and Avanti. Also there are power seeking politicians like the "impostor king."

On a still higher level, Sudarshana stands for human intellect, reason or knowledge, and Suranguma stands for faith, patience and perseverance. It is not by the power of intellect or reasoning that man can apprehend God, but by faith alone. Intellect may be very closely related to wisdom as the queen is to the King. But man's wisdom which excludes faith can never apprehend God. The message of the play is almost a warning to the man of science.

The impostor king represents the ignorance and self-deceptive tendencies in man's mind, and the conspirators, the evil forces in it. However, as the grandfather in the song points out, "We struggle and dig our own path, thus reach His path at the end." (172) Thus the drama answers how and why there is evil in life while God is all goodness and perfection. Villains, traitors, and impostors, in this world, are given freedom to do whatever they like and yet they are saved by repentance and are forgiven either in this birth or in a birth to come.

The song of the grandfather is not only a summary of the play, but also an assertion of man's free existence in the kingdom of God.

"We are all kings in the kingdom of our King.

Were it not so, how could we hope in our heart to meet him?

We do what we like, yet we do what he likes.

We are not bound with the chain of fear at the feet of a slave-owning king.

Were it not so, how could we hope in our heart to meet him?

Our King honours each one of us thus honours his own very self

We struggle and dig our own path thus reach His path at the end

We can never lost in the abyss of dark night

Were it not so, how could we hope in our heart to meet him?"(166) 
The symbolic significance of the play has attracted the notice of a host of scholars and critics, who have given different interpretations of the play. Radha Krishnan, in The Philosophy of Tagore gives the following interpretation of the play: "An individual cannot reach the ideal so long as fragments of finiteness stick to him, so long as intellect and will are bound to the realm of finite nature." ${ }^{10} \mathrm{P}$. Guha regards the theme of the play to be the realization of truth through suffering and sorrow. Other critics interpret the play in terms of allegorical symbols. The real King is Truth or God or Life-Spirit: queen Sudarshana is the individual soul, Suvarna is illusion, Kanchi is the symbol of mind, and the maid Surangama symbols self-surrender.

Dr. B.C. Chakravarthy states "The King of the Dark Chamber is a remarkable achievement of Rabindranath Tagore in the domain of symbolist art. The King stands for God of the universal soul and the Dark Chamber represents the inner consciousness of man, queen Sudarshana stands for the human soul. The King is dark and unseen because God is formless and cannot be seen with the physical eye". ${ }^{11}$ When the human soul is captivated by the various forms of sensuous beauty, it is doomed to destruction. When queen Sudarshana is enticed by the outward glamour of Suvarna, the result is suffering and destruction. When the human soul is purified, it is attracted by the magnificent beauty of the formless; queen Sudarshana also ultimately realizes the superb beauty of the King. It is not necessary to keep oneself confined to the inner consciousness. God should be realized among men and women in the wide universe for He is the tiller of the hard ground and the path maker.

\section{CONCLUSIONS}

Krishna Shah, basing the play on Tagore's doctrine of the Life-Spirit, observes that the invisible king of the dark chamber is the divinity of man. "When one comes to a realization of one's own soul, one is no longer dwelling in the 'dark chamber' but in the light of the divinity". ${ }^{12}$ Describing the play in terms of Tagore's doctrine of the Life-Spirit, Krishna Shah observes: "the individual soul with all its pride, egoistic impulse, foolish desire and curiosity must pass through the struggle to achieve union with the soul of the universe. The struggle is with one's own self. The place is the dark chamber of the heart. In other words, the Truth or the Soul of the Universe can only be discovered in the dark chamber of the heart through faith and not through rationalization". ${ }^{13}$

\section{REFERENCES}

1. Quoted by Hiran kumar sanyal. "The Plays of Tagore”, in the Tagore Centenary Volume. New Delhi: Sahitya Academy, 1961. 235.

2. Nirmal Mukherji. "The Plays of Rabindranath Tagore”, Perspectives on Indian Drama in English, ed. By M.K.Naik. Chennai: Oxford University Press, 1977. 59.

3. Edward Thompson. Rabindranath Tagore: Poet and Dramatist rev. ed. Oxford University Press: London, 1948. 126.

4. Kathopanishad, Chapter I, Valli 2, Shloka 5 and 6.

5. Rabindranath Tagore. Sadhana. Macmillan India, 1988. 65.

6. Rabindranath Tagore. Sadhana. Macmillan India, 1988. 60.

7. Sujit Mukherjee. Passage to America. Kolkatta, Bookland, 1964. 148.

8. S.C. Sen Gupta. The Great Sentinel: A Study of Rabindranath Tagore. Kolkatta: A Mukherjee \& co., 1948. 175.

9. Elder Olson. William Empson, Contemporary Criticism and Poetic Diction in Critics and Criticism ed. R.S. Crane, Chicago, 
1957. 46.

10. S. Radha Krishanan. The Philosophy of Tagore. London: Macmillan, 1918. 75.

11. Quoted by B.C. Chakravarthy: Rabinranath Tagore; His Mind and Art. New Delhi: Young India Publication, 55.

12. Krishna Shah. “Tagore’s English Gitanjali.” The Banasthali Patrika.1954. 123.

13. Krishna Shah. "Tagore's English Gitanjali.” The Banasthali Patrika.1954. 123. 
